\title{
Health Policy Effects on Health Systems
}

\author{
Karen M. Ott
}

\section{INTRODUCTION}

Healthcare systems in the United States rely on health policy regulation to ensure that the appropriate amount of consideration is given to the quality, access, equity, efficiency, cost, and defragmentation of their professional practices. One of the most major health policies in decades, the 2010 Patient Protection and Affordable Care Act (ACA), increased both health insurance coverage for Americans and access to care (Courtemanche et al., 2018). ACA's intent was to ensure that all clinicians have the ability to practice to the full extent of their skills and training, with the ability to practice across state lines when required by healthcare organizations and, the ability to be reimbursed for products and services (Rosenbaum, 2011).

Healthcare systems must also continue to be cognizant of new and evolving regulatory guidance and rules in addition to federal and state laws. Emerging health crises such as the COVID-19 pandemic, places new emphasis on the regulatory environment and is likely to continue. In this way, healthcare professionals and those who are responsible for healthcare administration need to be cognizant of the entire legal environment (Larrat et al., 2012). What current policies and regulations have helped shape and transform Advanced Practice Registered Nurse (APRN) practice in healthcare systems? How can APRNs shape future policies and regulation to continue to transform practice in healthcare systems?

\section{CURRENT POLICY, REGULATIONS, PUBLISHED EVIDENCE, AND THE POTENTIAL IMPACT ON HEALTHCARE SYSTEMS}

Many federal and state policies and regulations enacted within the past 5 years have had a substantial impact on the expansion of APRN practice. These policies and regulations reflect emerging public recognition and support for healthcare delivery systems that provide high quality care and services that are convenient, efficient, thorough, and safe.

\section{The Current and Most Influential Healthcare Policies/Regulations} (2016-2021)

Table 2.1 lists the healthcare policies and Federal/State regulations recognized by professional nursing organizations as having the most significant impact on the practice of all four APRN roles. These policies/regulations are grouped by topic and linked with the related available published studies/evidence and application to APRN practice.

\section{How Policy, Regulations, and Evidence Can Drive Change to Healthcare System Policy for the Application of Advanced Practice Registered Nurse Practice}

A healthcare system requires many elements to be successful: (a) trained and motivated health workers, (b) infrastructure, (c) a consistent supply of required resources and technology, (d) appropriate funding, (e) effective health plans, and (f) evidence-based policies (World Health Organization, 2021). For healthcare systems with facilities located in rural and other underserved areas, an 
TABLE 2.1 Healthcare Policies and Federal/State Regulations

\begin{tabular}{|c|c|c|c|}
\hline Topic & Policy/Regulation & Requirements & $\begin{array}{l}\text { Impact/Application } \\
\text { to ARPN Practice }\end{array}$ \\
\hline \multirow[t]{3}{*}{$\begin{array}{l}\text { Federal } \\
\text { Legislative } \\
\text { Responses to } \\
\text { Public Crises }\end{array}$} & $\begin{array}{l}2016 \\
\text { Comprehensive } \\
\text { Addiction \& } \\
\text { Recovery Act } \\
\text { (CARA) }\end{array}$ & $\begin{array}{l}\text { Established a set of provisions } \\
\text { to address the opioid } \\
\text { epidemic. Authorized Nurse } \\
\text { Practitioners (NP) and } \\
\text { Physician Assistants (PA) to } \\
\text { obtain a Drug Enforcement } \\
\text { Administration (DEA) waiver } \\
\text { to prescribe buprenorphine } \\
\text { to treat Opioid Use Disorder } \\
\text { (OUD) }\end{array}$ & $\begin{array}{l}2019 \text { research } \\
\text { study concluded } \\
\text { that the ability of } \\
\text { NPs to prescribe } \\
\text { buprenorphine } \\
\text { resulted in a "strong } \\
\text { and robust" increase } \\
\text { in the number of } \\
\text { buprenorphine } \\
\text { prescribers, } \\
\text { especially NPs, and } \\
\text { patients. Findings } \\
\text { also found that } \\
\text { "states with full } \\
\text { NP prescriptive } \\
\text { authority had a } \\
\text { higher proportion } \\
\text { of advanced } \\
\text { practitioner } \\
\text { prescribers than did } \\
\text { states with limited } \\
\text { NP prescriptive } \\
\text { authority" (Varghese } \\
\text { et al., 2019). }\end{array}$ \\
\hline & $\begin{array}{l}2018 \text { Substance } \\
\text { Use-Disorder } \\
\text { Prevention that } \\
\text { Promotes Opioid } \\
\text { Recovery and } \\
\text { Treatment for } \\
\text { Patients and } \\
\text { Communities Act } \\
\text { (SUPPORT) }\end{array}$ & $\begin{array}{l}\text { Extended waiver eligibility to } \\
\text { Certified Nurse Midwives } \\
\text { (CNM), Clinical Nurse } \\
\text { Specialists (CNS), and } \\
\text { Certified Registered Nurse } \\
\text { Anesthetists (CRNA) }\end{array}$ & $\begin{array}{l}\text { No published studies } \\
\text { or impact related to } \\
\text { this law to date. }\end{array}$ \\
\hline & $\begin{array}{l}2020 \text { Coronavirus } \\
\text { Aid, Relief, } \\
\text { and Economic } \\
\text { Security Act } \\
\text { (CARES Act) }\end{array}$ & $\begin{array}{l}\text { Provided broad "blanket } \\
\text { waivers" for NPs and PAs } \\
\text { to order home care services } \\
\text { for patients to ensure access } \\
\text { to services and continuity } \\
\text { of care while avoiding } \\
\text { unnecessary exposure to the } \\
\text { COVID-19 virus particularly } \\
\text { for patients who live in rural } \\
\text { and medically underserved } \\
\text { communities. This law also } \\
\text { authorized additional } \\
\text { telehealth waivers to expand } \\
\text { the types of healthcare } \\
\text { professionals to deliver } \\
\text { healthcare via telehealth to } \\
\text { eligible Medicare recipients. }\end{array}$ & $\begin{array}{l}\text { No published studies } \\
\text { or impact related to } \\
\text { this law to date. }\end{array}$ \\
\hline
\end{tabular}


TABLE 2.1 Healthcare Policies and Federal/State Regulations (continued)

\begin{tabular}{|c|c|c|c|}
\hline Topic & Policy/Regulation & Requirements & $\begin{array}{l}\text { Impact/Application } \\
\text { to ARPN Practice }\end{array}$ \\
\hline $\begin{array}{l}\text { Centers for } \\
\text { Medicare } \\
\text { \& Medicaid } \\
\text { Services (CMS) } \\
\text { Waiver of Code } \\
\text { of Federal } \\
\text { Regulations } \\
\text { (CFR) }\end{array}$ & $\begin{array}{l}\text { December } 2020 \\
\text { COVID-19 } \\
\text { Emergency } \\
\text { Declaration } \\
\text { Blanket Waivers } \\
\text { for Healthcare } \\
\text { Providers (42 } \\
\text { CFR } \$ 482.41 \\
\text { and } 42 \text { CFR } \\
\S 485.623)\end{array}$ & $\begin{array}{l}\text { CMS waived the following } \\
\text { requirements to increase } \\
\text { flexibilities for surge capacity } \\
\text { and patient quarantine } \\
\text { at hospitals, psychiatric } \\
\text { hospitals, and critical access } \\
\text { hospitals (CAHs) as a result } \\
\text { of COVID-19: } \\
\text { That Medicare patients be } \\
\text { under the care of a physician. } \\
\text { That a CRNA is under the } \\
\text { supervision of a physician } \\
\text { (CRNA supervision is still at } \\
\text { the discretion of the hospital } \\
\text { and state law). } \\
\text { That physicians must provide } \\
\text { direction and supervision of } \\
\text { NPs. } \\
\text { The ability of CAH to use NPs } \\
\text { and PAs "to the fullest extent } \\
\text { possible." } \\
\text { For a physician to not be able } \\
\text { to delegate tasks to NPs, } \\
\text { PAs, and CNS' who meet } \\
\text { state licensure and scope of } \\
\text { practice laws. } \\
\text { For physicians to make visits } \\
\text { personally without the ability } \\
\text { to delegate the visit to an NP } \\
\text { or PA. } \\
\text { The minimum personnel } \\
\text { qualifications for CNS', NPs } \\
\text { and PAs if these providers } \\
\text { meet state licensure } \\
\text { requirements and the staffing } \\
\text { flexibilities are consistent } \\
\text { with state's emergency } \\
\text { preparedness or pandemic } \\
\text { plan. } \\
\text { licensed in the state where } \\
\text { they are providing services. } \\
\text { for the appointment and } \\
\text { credentialing of physicians, } \\
\text { NPs, PAs, and CNS' to be } \\
\text { in accordance with state } \\
\text { law if they are consistent } \\
\text { with state's emergency } \\
\text { preparedness or pandemic } \\
\text { Requirement for an out-of- }\end{array}$ & $\begin{array}{l}\text { No published } \\
\text { evidence or impact } \\
\text { related to these } \\
\text { regulations to date }\end{array}$ \\
\hline
\end{tabular}


TABLE 2.1 Healthcare Policies and Federal/State Regulations (continued)

\begin{tabular}{|c|c|c|c|}
\hline Topic & Policy/Regulation & Requirements & $\begin{array}{l}\text { Impact/Application } \\
\text { to ARPN Practice }\end{array}$ \\
\hline $\begin{array}{l}\text { APRN } \\
\text { Reimbursement }\end{array}$ & $\begin{array}{l}2021 \\
\text { Consolidated } \\
\text { Appropriations } \\
\text { Act that } \\
\text { incorporated the } \\
\text { "No Surprises } \\
\text { Act" }\end{array}$ & $\begin{array}{l}\text { Prohibits health plans and } \\
\text { out-of-network healthcare } \\
\text { providers from billing health } \\
\text { plan enrollees above in- } \\
\text { network amounts in certain } \\
\text { situations. More importantly, } \\
\text { this law allows providers and } \\
\text { insurers the opportunity to } \\
\text { negotiate reimbursement } \\
\text { for provided services related } \\
\text { to emergency medicine, } \\
\text { anesthesiology, pathology, } \\
\text { radiology and, neonatology } \\
\text { whether these services are } \\
\text { provided by a physician or a } \\
\text { non physician practitioner. }\end{array}$ & $\begin{array}{l}\text { No published } \\
\text { evidence or impact } \\
\text { related to this law to } \\
\text { date. }\end{array}$ \\
\hline $\begin{array}{l}\text { Representation } \\
\text { on National } \\
\text { Committees }\end{array}$ & $\begin{array}{l}2018 \text { Preventing } \\
\text { Maternal Deaths } \\
\text { Act }\end{array}$ & $\begin{array}{l}\text { Set up federal infrastructure } \\
\text { and resources to collect/ } \\
\text { analyze data on the death } \\
\text { of every expectant and new } \\
\text { mother in every state. Also } \\
\text { established federal funding } \\
\text { and support for existing } \\
\text { maternal mortality review } \\
\text { committees (MMRCs) in } \\
\text { states and tribal nations. } \\
\text { MMRCs collect information } \\
\text { to understand factors related } \\
\text { to deaths during pregnancy, } \\
\text { delivery, and the postpartum } \\
\text { period. }\end{array}$ & $\begin{array}{l}\text { The American College } \\
\text { of Nurse Mid-Wives } \\
\text { have been able } \\
\text { to appoint CNMs } \\
\text { on every state } \\
\text { MMRC to provide } \\
\text { recommendations } \\
\text { and develop } \\
\text { strategies to prevent } \\
\text { issues during } \\
\text { the prenatal and } \\
\text { postpartum period. }\end{array}$ \\
\hline $\begin{array}{l}\text { Data Collection } \\
\text { for National } \\
\text { Healthcare } \\
\text { Professional } \\
\text { Shortages }\end{array}$ & $\begin{array}{l}2018 \text { Improving } \\
\text { Access to } \\
\text { Maternity Care } \\
\text { Act requires the } \\
\text { Health Resources } \\
\text { and Services } \\
\text { Administration } \\
\text { (HRSA) to } \\
\text { identify areas } \\
\text { with maternity } \\
\text { care health } \\
\text { professional } \\
\text { shortages }\end{array}$ & $\begin{array}{l}\text { HRSA are required to collect/ } \\
\text { publish data comparing } \\
\text { maternity health-are needs } \\
\text { and professional shortages. }\end{array}$ & $\begin{array}{l}\text { CNMs were not } \\
\text { allowed to be a } \\
\text { major designation } \\
\text { under HRSA so the } \\
\text { discrete impact of } \\
\text { CNM contributions } \\
\text { will not be } \\
\text { measured. }\end{array}$ \\
\hline
\end{tabular}


additional requirement includes employing clinical staff who have the appropriate education, skills, and cultural competency to meet the needs of the communities they serve (Rural Health Information Hub, 2020).

This requirement is even more important in light of a 2021 finding that for low-income older adults who live in U.S. rural areas, there is evidence of an increasing gap in the mortality rates between the rural Medicare beneficiaries and their urban counterparts (Loccoh et al., 2021).

In the recent past, the crossroads of three important factors occurred that provides both healthcare leaders and APRNs with a major opportunity to improve both patient care delivery and patient outcomes: First, there has been a growing amount of extensive evidence in the literature that validates and supports the quality, safety, and efficiency of expanded APRN practice. Second, the 2020 Regulations from the Centers for Medicare and Medicaid Services (2020) that issued COVID-19 Blanket Waivers for required NP supervision in Rural Health Centers and Federally Qualified Health Centers and required CRNA supervision in hospitals, Critical Access Hospitals, and Ambulatory Surgical Centers. The third and final factor is the increasing numbers of NPs practicing in both rural and non-rural primary care (Barnes et al., 2018). These three factors taken together, along with increasing public recognition for the value that APRNs bring to the delivery of healthcare ranging from the simple to the complex, underscore the potential and significant value that the expansion of APRN roles will have an impact on in two predominant settings-rural/underserved areas and primary care locations.

For APRNs overall, the Institute of Medicine (now the National Academy of Medicine) Report on The Future of Nursing: Leading Change, Advancing Health, recommended that APRNs be able to practice to the full scope of practice to which they are educated and trained (Institute of Medicine, 2011). Following this report, two studies conducted systematic reviews of state NP practice regulations and healthcare delivery outcomes that support the IOM Report and, found that APRN full practice authority laws expanded the access of care in rural and underserved populations without decreasing the quality of patient outcomes (Ortiz et al., 2018; Yang et al., 2019).

For NPs specifically, Jackson et al. (2018) found no clinically significant differences in intermediate diabetes outcomes while maintaining quality standards among physician, NP and PA primary care providers. These findings support the expansion of primary care access with the most cost-efficient provider practice throughout the entire healthcare delivery system (Jackson et al., 2018).

Evidence supports a strong statistical correlation between the full practice of NPs and preventable hospitalization rates in the Medicare-Medicaid population for the readmission rate in post-acute hospital care for rehabilitation; hospital rates in the nursing home setting; and overall health outcomes (Oliver et al., 2014).

For CRNAs specifically, Coomer et al. (2019) examined 2014 CMS claims data to determine the impact of the CMS 2001 opt-out policy for CRNA supervision on anesthesia staffing models in hospital and ambulatory surgery centers. The authors found that individual facility characteristics and rural/urban considerations played a more significant role in facilities' use of anesthesia service delivery models than a State's opt-out status. Secondarily, the authors concluded that allowing CRNAs to provide anesthesia services without the need for anesthesiologist supervision may help alleviate anesthesiology provider shortages and reduce total anesthesia delivery costs, without negatively affecting quality of care particularly in rural locations (Coomer et al., 2019). In addition, the Centers for Medicare \& Medicaid Services (CMS) Final Regulation (November 13, 2001) that allowed states to opt-out of the federal supervision requirement for physician supervision of CRNAs, now includes 19 states (as of January 2020) that have opted out of the federal requirement (R. Kohl, personal communication, February 11, 2021).

For CNMs specifically, Ranchoff and Declercq (2020) found that restrictive practice environments for CNMs are related to women's access to maternity and reproductive health services from these providers. They further suggest that expanding midwifery practice in states with restrictive environments may significantly improve access to maternity care services. In addition, CNMs and corresponding documentation for the rise of maternity care that strongly suggests the need for regulatory reform (Ranchoff \& Declercq, 2020).

Exhibit 2.1 is an example of the impact of full practice authority on three APRNs roles in a very large national healthcare system. 
EXHIBIT 2.1 AN EXAMPLE OF THE IMPACT OF ADVANCED PRACTICE REGISTERED NURSE FULL PRACTICE AUTHORITY ON A HEALTHCARE SYSTEM

The Veterans Health Administration (VHA) is one of the largest healthcare systems in the United States with over 8,000 APRNs (CNP, CRNA, and CNS) who practice in 1,255 healthcare facilities including 170 medical centers and 1,074 ambulatory care sites of varying complexity (known as Community Based Outpatient Clinics) and, that serve nine million enrolled veterans each year (as of February, 2021) in all 50 states plus the District of Columbia, Guam, Puerto Rico and the U.S. Virgin Islands (www.va.gov/health).

As a federal agency, VHA has the authority to regulate the practice of its providers regardless of state law (Department of Veterans Affairs, 2021). In January 2017, VHA issued a Final Rule published in the Federal Register that authorized Full Practice Authority (FPA) for three of the four APRNs roles (CNP, CNS, CNM) allowing these APRNs to practice to the full extent of their education and training while employed with the VA. As of September 30, 2020, all VHA medical facilities fully implemented FPA including revision of the bylaws.

The FPA regulation removed scope of practice (SOP) barriers for mandatory collaboration/ supervisory agreements with physicians regulated by individual state statute. With the authority for full practice, APRNs are now able to practice to their maximum potential and across state lines based upon veteran needs. This is especially significant for clinical areas including the Clinical Contact (Call) Centers, Interim Staffing Resource Centers and the telehealth arena and, for the delivery of critical services to veterans in rural and underserved areas.

This action was taken (according to a Department of Veterans Affairs press release in May 2016) to "expand the pool of qualified healthcare professionals authorized to provide primary healthcare and other related healthcare services to the full extent of their education, training, and certification to Veterans without the clinical supervision of a physician" and, "to ensure VA has authority to address staffing shortages in the future" (Department of Veterans Affairs, 2016).

A preliminary evaluation of the FPA policy was conducted by measuring the impact on patient access, specifically the wait times for new patient appointments in primary, specialty and mental health services. The results indicated that VA medical facilities implementing FPA early on showed reduced wait times for new patient appointments within 30 days of their preferred date for primary care, specialty care, and mental health. These results align with previous published literature demonstrating access to care can be improved with APRN providers (Rugs et al., 2021).

\section{The Importance of Advanced Practice Registered Nurse Influence and Representation on Future Health Policy}

Health policies must be able to define and integrate the standards needed for the appropriate delivery of care throughout entire health systems. Policies must also address the environmental elements necessary to ensure that care is delivered with the appropriate resources and requirements to ensure patient quality, safety and, access (Burke, 2016). That said, APRNs can have the greatest impact on the development of new policy through their influence and representation on federal and state committees or with local/regional community organizations to support FPA in every state and territory. The support for FPA in every state and U.S. Territory remains the highest policy priority identified by representatives of professional nursing organizations (M. Sapio \& T. Kopanos, personal communication, February 3, 2021) and (A. Kohl, personal communication, February 15, 2021).

Even in those states that have FPA policies, APRNs may need to exert their influence on internal health system policies, for example, hospital bylaws, that limit their practice.

\section{POLICY ADVOCACY CONSIDERATIONS FOR EDUCATORS AND ADMINISTRATORS}

Health policy courses are a fundamental element to the current curricula of many Doctor of Nursing Practice programs. These courses provide educators with the opportunity to inspire and shape 
student activities toward practice advocacy. In similar fashion, a workplace setting can provide the same opportunity to influence APRNs. Nurse administrators and leaders can motivate or encourage APRNs to become and remain politically active throughout their careers. In either setting, knowledge of current health policy is essential to support and encourage student/staff advocacy for political involvement.

\section{Examples of Actions for Educators, Administrators, and Advanced Practice Registered Nurses}

The examples below describe actions that educators, administrators, and APRN's can undertake as activists for policy and practice:

1. Becoming familiar with the content of one's state practice act to identify and understand existing barriers to APRN practice.

2. Encouraging the development of DNP projects aimed at changing federal or state policies that support APRN practice and patient needs.

3. Inviting political leaders to lecture in academic programs.

4. Sustaining membership in professional organizations to build political support and advocacy.

5. Maintaining contacts and connections with academic alumna who are in positions of influence.

6. Initiating conversations with state legislators and, with clinical disciplines with whom APRNs share clinical practice responsibilities, e.g., PA, pharmacists, and physicians to identify and address the positive and negative implications of current policies for their practice.

7. Contacting federal lawmakers to advocate for changes in reimbursement for CMS services and, to reduce variation in practice within large healthcare systems that provide services in multiple states; and,

8. Engaging in letter-writing to state and federal representatives to achieve specific political aims.

9. Providing both evidence and the solutions to address costs, safety, and quality issues when advocating for policy change.

\section{Synthesis Exercises for Academic and Workplace Settings}

The two synthesis exercises below provide practical scenarios for the classroom and for the workplace intended to promote constructive political action and advance the practice for all four APRN roles. This four-step targeted exercise is intended to encourage DNP students to create and develop ideas intended to influence federal or state policy to deregulate APRN practice and increase patient access.

I. Brainstorming: Goal: To move from knowledge of course material (readings, lectures, etc.) to a more synthesized understanding (thinking, sorting, comparing, applying, etc.) that leads to new perspectives and understanding about the material.

a. Brainstorming promotes the move to deeper understanding by providing DNP students with the opportunities to externalize their ideas and understand the relationships between them. Examples of brainstorming include the following:

i. Timed "free-writing" of ideas/topics

ii. Timed "free-association" of words/phrases

iii. Identifying connected subjects

iv. Using journalistic questions (who, what, when, where, how, and why) to expand thinking and

v. Applying ideas to familiar or personal situations.

II. Organizing: Goal: Choose and shape ideas

a. Examples of how to organize ideas include:

i. Sorting ideas into separate piles 
ii. Role-playing with students who disagree with the idea to help shift ideas

iii. Explaining/teaching the ideas to another person to "identify the holes"

iv. Identifying elements through a "problem-solving lens"

v. Theory-testing to examine whether it could apply to new or similar situations

vi. The ability to adequately summarize the most critical questions or issues

vii. The ability to find supporting evidence in the literature and,

viii. Rewriting the ideas over a period of several days.

III. Drafting: Goal: Move ideas to a more "complete and coherent" form

a. Examples of types of drafts include the following:

i. Turning the ideas into a five-minute speech to identify the main points

ii. Creating an outline to determine the logical flow of ideas

iii. Writing out the easiest part of the draft first

iv. Writing out alternatives to test more than one idea and,

v. Writing a practice full draft to identify the most important ideas.

IV. Revising: Goal: Decide what changes are needed for word choices, the organization and logic of ideas, supporting evidence, and the tone used in the draft.

a. Examples of revision actions include the following:

i. Getting a reaction from others after presenting the document

ii. Understanding your own reaction after the document is read back

iii. Asking a reader to look for specific feedback on organization, transitions, punctuation, etc.

iv. Sharing the strengths and weaknesses of the document with the instructor

v. Analyzing the draft as a list of discrete sentences to resolve sentence-level problems

vi. Looking at the key terms used to convey ideas to see if the ideas are adequately explained

vii. Underlining the main point of the draft to ensure it is located somewhere near the beginning of the draft. (The Writing Center, 2021)

This white paper format can be introduced to practicing APRNs by nurse managers and leaders in the workplace to address restrictive APRN practices such as hospital bylaws.

\section{Introduction:}

(1). Write your selected title for the white paper.

(2). Write a brief description of the issue or project (1 or 2 paragraphs).

(3). Identify the estimated length of time to complete the issue/project.

\section{Background:}

(1). Describe the history of your department/organization.

(2). Describe the expertise and knowledge available to address the issue.

(3). Describe similar successes of prior work and the outcome.

III. Need:

(1). Write several paragraphs illustrating the definition of the issue or need.

(2). Write several paragraphs describing the significance of the issue/need.

\section{Solution:}

(1). Write several paragraphs outlining your solutions to the issue/need.

(2). Describe how, when, and with what resources solutions will take place.

(3). Describe the methodology to be implemented in the solution of the issue.

(4). Create a simple timeline of the project. 
V. Benefits: (Quality and Safety Issues)

(1). Describe how your solution will bring new thought to the issue.

(2). Describe how your solution will benefit the staff, healthcare system, patients, state, and potentially to healthcare in general.

\section{Evaluation:}

(1). Describe the details of the program evaluation that will validate the success/failure of the project (quality, safety, economic impacts)

(2). Tell how the evaluation will be made available to the healthcare system level leadership.

\section{Costs:}

(1). Identify a Principal Investigator and the associated percentage of time required to successfully accomplish the entire project.

(2). Identify other consultants and the associated percentage of time required to successfully accomplish the project.

(3). Identify the number of APRN practitioners required to accomplish the project.

(4). Identify any equipment needed to successfully accomplish the task

(5). Estimate the number of local travel that is dedicated to the project.

(6). Estimate the number of trips required, location, length of stay, etc. (WordLayouts ${ }^{\circledR}, 2021$ )

\section{CONCLUSION}

The need for political engagement is the obligation of every professional healthcare discipline and APRNs are no exception. Although the very nature of APRN daily practice can potentially impact the healthcare delivery, the influence on healthcare policy must be even more deliberate.

Advocacy is essential and there are a multitude of ways in which APRNs can influence healthcare policy: (a) The completion of quality improvement projects; (b) Attendance at community meetings where issues are discussed and debated in order to share their knowledge and expertise on health-related issues (Chilton, 2015); (c) The ability to provide both evidence and solutions to address costs, safety, and quality issues; and, (d) Active support for additional federal initiatives that include funding for training and education as well as for models of care where APRNs practice.

There is evidence that healthcare has been and will continue to be a factor in future congressional elections. APRNs must become competent in the political process and skillful in the art of compromise, commitment, and perseverance. In addition, it is essential that APRNs become for familiar with their political representatives to advocate for the needs of their patients as well as the communities in which they live (Kostas-Polston et al., 2015). Using these skills, APRNs can directly influence healthcare policy and set the course for future practice. 


\section{End-of-Chapter Resources}

\section{DISCUSSION QUESTIONS}

These questions are designed to help APRNs become active advocates for their practice:

1. What role does APRN practice play in the development of health policy?

2. What health policies have had the greatest impact on APRN practice in their health systems?

3. What is the impact of current healthcare policy on clinicians other than APRNs?

4. How do geographical and practice settings impact policy?

5. How will future challenges to the delivery of healthcare impact U.S. health policy?

6. How will market forces continue to evolve in the healthcare delivery system?

\section{ANALYSIS, SYNTHESIS, AND CLINICAL APPLICATION}

Through interviews with APRNs, the following interventions were recommended to improve the delivery of healthcare to patients:

1. Working with state legislative representatives can result in legislative changes that benefit APRN practice. An example was provided by an APRN who worked directly with his state representatives, educating them on APRN practice and the importance of increasing access to healthcare, resulting in the successful change to give APRN's FPA after completing 2,000 hours of practice after being first licensed (C. Singer, personal communication, 2021).

2. The creation of a practice environment where increased interprofessional practice among $A P R N s$ and other practitioners can improve health outcomes for patients, families, and communities is essential. This includes the coordination of care among multiple types of providers of care such as PA, physicians, Physical Therapists, Pharmacists, Chiropractors, Dentists, etc. (C. Singer, personal communication, 2021).

3. Robust and effective residency programs are important to APRNs to belp understand and transition into their role. This is especially important for those who will practice in medical or surgical specialties than benefit the most from residencies (M. Lucatorto, personal communication, 2021).

Many strategies have been proposed in the literature to enhance the future of healthcare delivery. One such analytics and advisory company, the Gallup Corporation, conducted research in the healthcare field that resulted in the following list of five forces important to the future of healthcare systems. The following strategies are based on a 2020 Gallup Poll showing that the percentage of Americans who are "very satisfied" with the quality of medical care remains around $19 \%$, a percentage that hasn't changed to a great degree in the past 20 years (Ratanjee, 2020).

1. Instituting value-based care will create a shift from conventional thinking and legacy processes for the how, where and by whom care is delivered. Value-based care must be driven by the patient experience, cost economies, recognition for caregiver needs, and attention to population health.

2. Preparing for the constant disruptions caused by the advent of unknown illnesses, new technology, and macroeconomic factors will reshape how healthcare is delivered.

3. Planning for the widespread and increasing acceptance of virtual and physical healthcare locations outside of the traditional hospital settings especially, in rural and underserved areas.

4. Maximizing the healthcare's system of stakeholders to include non-traditional industry partners will help provide information to transform healthcare and improve accessibility.

5. Evolving as an organization to engage the collective talent of private and public enterprises will improve the quality and cost of delivering healthcare (Ratanjee, 2020). 


\section{ADDITIONAL RESOURCES}

\section{A robust set of instructor resources designed to supplement this text is located at http://connect.springerpub.com/content/book/978-0-8261-5464-4. Qualifying instructors may request access by emailing textbook@springerpub.com.}

\section{REFERENCES}

Barnes, H., Richards, M. R., McHugh, M. D., \& Martsolf, G. (2018). Rural and nonrural primary care physician practices increasingly rely on nurse practitioners. Health Affairs, 37(6). https://doi.org/10.1377/ hlthaff.2017.1158

Burke, S. (2016). Influence through policy: Nurses have a unique role. https://nursingcentered.sigmanursing.org/ commentary/more-commentary/Vol42_2_nurses-have-a-unique-role

Centers for Medicare and Medicaid Services. (2020). COVID-19 emergency declaration blanket waivers for healthcare providers. https://www.rand.org/content/dam/rand/pubs/rgs_dissertations/RGSD300/RGSD396/ RAND_RGSD396.pdf

Chilton, L. (2015). Nurse practitioners have an essential role in health policy. The Journal for Nurse Practitioners, 11(2), A19. https://doi.org/10.1016/j.nurpra.2014.10.009

Coomer,N.M.,Mills,A.,Beadles, C., Gillen,E.,Chew,R., \& Quraishi,J.A.(2019).Anesthesia staffing models and geographic prevalence post-medicare CRNA/physician exemption policy. Nursing Economics, 37(2), 86-91. https:// search.proquest.com/openview/3f55b0d94533f910b7c0c1dc5d7202bc/1 ?pq-origsite = gscholar \&cbl $=30765$

Courtemanche, C., Marton, J., Ukert, B., Yelowitz, A., \& Zapata, D. (2018). Effects of the affordable care act on healthcare access and self-assessed health after 3 years. Inquiry. https://doi.org/10.1177/0046958018796361

Department of Veterans Affairs. (2016). Press release statement by Dr. David J. Shulkin. VA Office of Public and Intergovernmental Affairs. https://www.va.gov/opa/pressrel/pressrelease.cfm?id=2847

Department of Veterans Affairs. (2021). Veterans health administration. https://www.va.gov/health

Institute of Medicine. (2011). The future of nursing: Leading change, advancing health (pp. 9-11). The National Academies Press.

Jackson, G. L., Smith, V. A., Edelman, D., Woolson, S. L., Hendrix, C. C., Everett, C. M., Berkowitz, T. S., White, B. S., \& Morgan, P. A. (2018). Intermediate diabetes outcomes in patients managed by physicians, nurse practitioners, or physician assistants. Annals of Internal Medicine, 169(12), 825-835. https://doi.org/10.7326/ M17-1987

Kostas-Polston, E. A., Thanavaro, J., Arvidson, C., Taub, L. M., \& FAANP Health Policy Work Group. (2015). Advanced practice nursing: Shaping health through policy. Journal of the American Association of Nurse Practitioners, 27(1), 11-20. https://doi.org/10.1002/2327-6924.12192

Larrat, P. E., Marcoux, R. M., \& Vogenberg, F. R. (2012). Impact of federal and state legal trends on healthcare services. Pharmacy \& Therapeutics, 37(4), 218-220, 224-226. https:/www.ncbi.nlm.nih.gov/pmc/articles/ PMC3351856

Loccoh, E., Joynt Maddox, K. E., Xu, J., Changyu, S., Figueroa, J. F., Dhruv S. K., Yeh, R.W., \& Rishi K. W. (2021). Rural-urban disparities in all-cause mortality among low-income medicare beneficiaries, 2004-17. Health Affairs, 40(2). https://doi.org/10.1377/hlthaff.2020.00420

Oliver, G. M., Pennington, L., Revelle, S., \& Rantz, M. (2014). Impact of nurse practitioners on health outcomes of medicare and Medicaid patients. Nursing Outlook, 62(6), 440-447. https://doi.org/10.1016/j .outlook.2014.07.004

Ortiz, J., Hofler, R., Bushy, A., Lin, Y., \& Khanijahanl, A. (2018). Impact of nurse practitioner practice regulations on rural population health outcomes. Healthcare, 6(2), 65. https://doi.org/10.3390/healthcare6020065

Ranchoff, B. L., \& Declercq, E. R. (2020). The scope of midwifery practice regulations and the availability of the certified nurse-midwifery and certified midwifery workforce, 2012-2016. Journal of Midwifery \& Womens Health, 65(1), 119-130. https://doi.org/10.1111/jmwh.13007

Ratanjee, V. (2020). Five forces that will reshape the future of healthcare. https://www.gallup.com/workplace/323039/five-forces-reshape-future-healthcare.aspx

Rosenbaum, S. (2011). The patient protection and affordable care act: Implications for public health policy and practice. Public Health Report, 126(1), 130-135. https://doi.org/10.1177/003335491112600118

Rugs, D., Toyinbo, P., Barrett, B., Melillo, C., Chavez, M., Cowan, L., Jensen, P. K., Engstrom, C., Battaglia, C., Thorne-Odem, S., Sullivan, S. C., \& Powell-Cope, G. (2021). A preliminary evaluation of full practice authority of advanced practice registered nurses in the Veterans Health Administration. Nursing Outlook, 69 (2), 147-158. https://doi.org/10.1016/j.outlook.2020.11.005

Rural Health Information Hub. (2020, November 9). Rural health workforce. https://www.ruralhealthinfo.org/ topics/health-care-workforce

Varghese, R., Johnson, K., Feng, B., Liu, M., Sanford, A., Dowell, P., Desai, K., Harris, I., \& Rajakannan, T. (2019). Final research report: Buprenorphine prescribing by nurse practitioners, physician assistants, and physicians after CARA. IMPAQ International, LLC. MACPAC. https://www.macpac.gov/wp-content/uploads/2019/11/ Buprenorphine-Prescribing-by-Nurse-Practitioners-Physician-Assistants-and-Physicians-after-CARA-2016 .pdf 
WordLayouts ${ }^{\circledR}$. (2021, April 12). White paper templates to help you in formatting your white papers. https:// www.wordlayouts.com/white-paper-template/

World Health Organization. (2021, February 23). https://www.who.int/healthsystems/about/en/

The Writing Center at the University of North Carolina at Chapel Hill. (2021, March 28). In-class writing exercises. https://writingcenter.unc.edu/faculty-resources/tips-on-teaching-writing/in-class-writing-exercises/

Yang, B. K., Johantgen, M. E., Trinkoff, A. M., Idzik, S. R., Wince, J., \& Tomlinson, C. (2019). State nurse practitioner practice regulations and U.S. healthcare delivery outcomes: A systemic review. Medical Care Research and Review. https://doi.org/10.1177/1077558719901216 